\title{
Spies in the Archive: Acquiring Revolutionary War Spy Letters Through Community Engagement
}

\section{Introduction}

Special Collections, a division of Stony Brook University Libraries (SBU Libraries), acquired at auction two American Revolutionary War-era spy letters authored by George Washington. Significant to regional and national historical narratives, the letters document espionage activities in the Three Village area of Long Island, New York, the site of an important war effort known as the Culper Spy Ring. The letters were obtained through a collaborative acquisition project established in the months preceding the first auction. A private-public partnership was initially formed to secure funding. Next, mindful of the spy ring's strong link to community identity, library representatives cultivated relationships with local cultural institutions to foster inclusiveness. Key to the process was articulating and reaffirming the shared goals to repatriate the letters, conserve them, and make them accessible at the university.

A review of library and higher education literature on collaborative acquisitions and on engagement as an impetus for acquisition revealed a lack of documentation. The article aims to address this gap by discussing how engagement activities began at the outset of an acquisition and how this novel approach led Special Collections to unique opportunities for outreach and a renewed focus for library collections. It also will reflect on the lessons learned and outcomes of the project, which may be instructive to institutions seeking to expand the reach of their collections.

\section{About the Institution \\ Stony Brook University}

Founded in 1957, Stony Brook University (SBU) is a public research university situated on the north shore of Long Island, approximately sixty miles east of New York City. Nestled on 1,000 acres within the Three Village area (comprising hamlets Stony Brook and Setauket, and the Incorporated Village of Old Field), the university is a member of the Association of American Universities and is Suffolk County's largest single-site employer. ${ }^{1}$ An impassioned assortment of historical societies and

\footnotetext{
1. "The Impact of Stony Brook University on the Long Island Economy," Stony Brook University, Center for Regional Policy Studies, available online at www.stonybrook.edu/sb/impact.shtml [accessed 1 October 2016].

*C 2017 by Kristen J. Nyitray and Sally Stieglitz (CC BY-NC-ND [https://creativecommons.org/ licenses/by-nc-nd/4.0/]).
} 
nonprofit organizations, including the Three Village Historical Society (TVHS), the Long Island Museum of American Art, History and Carriages (LIM), and the Ward Melville Heritage Organization (WMHO), are located in the immediate vicinity of the Stony Brook campus.

\section{Special Collections, Stony Brook University Libraries}

Curatorial oversight of the university's rare books, manuscripts, and maps is under the aegis of Special Collections and University Archives, a division of SBU Libraries. Staffed by one full-time faculty librarian, Kristen J. Nyitray (Department Head and University Archivist) and one professional support specialist, it is the largest repository of its type on Long Island (Nassau and Suffolk counties) with holdings of more than 50,000 titles and 400 collections. Founded in 1969, the department rapidly built its collections, ranging from the political papers of Senator Jacob K. Javits to the writings of Irish poet and playwright William Butler Yeats. Archives from local organizations and politicians were acquired in the first three decades along with books and maps of Long Island, but the scope of the collections lacked cohesiveness and access was limited due to their unprocessed status. In the past fifteen years, the department has transformed by implementing a diverse range of outreach activities, a strong online presence, and an ambitious collection processing schedule. Collections are now inventoried and cataloged to enhance access to researchers and in support of the SBU curriculum. The primary mode of acquisition is donation (tangible giftsin-kind); however, private funds are available for special, one-time purchases. Several financial endowments have been established by cultivating relationships with donors and alumni. To spur engagement with the university and external communities, a wide array of events is produced, including scholarly conferences, poetry readings, a faculty authors series, art crawls, and traveling exhibitions. When the opportunity emerged to seriously pursue and acquire the 1779 Washington spy letter, the department was poised to take a lead role in the process.

\section{Overview of the Literature}

What is the impetus for academic libraries to invest time and resources in outreach and engagement activities, with whom are they trying to connect, and what are the ultimate goals of the efforts? Assessments and studies on outreach are increasing, and, according to Boudewyns and Klug, "today's collection development goals are aligning with the emerging pedagogical behavior that favors discoverability and community engagement." ${ }^{\prime 2}$ Recent literature published in the disciplines of librarianship, archives and special collections, and higher education with an emphasis outreach and community engagement was reviewed. Themes identified include:

2. Deborah K. Boudewyns and Shannon L. Klug, "Collection Development Strategies for Community Engagement," Collection Management 39, no. $2 / 3$ (2014): 145. 
outreach as a means to promote awareness of collections, ${ }^{3}$ to change traditional perceptions of institutions, ${ }^{4}$ as a function of service, ${ }^{5}$ and how effective outreach can lead to mutually beneficial and engaging partnerships. ${ }^{6}$ However, studies on the narrower focus of engagement preceding acquisition were not found. ${ }^{7}$ This article seeks to contribute to the scholarship by demonstrating how engagement can be embarked upon prior to acquisition and can be integrated into collection development activities.

\section{Promoting Awareness of Collections}

"One of the most frustrating things for an archivist is to know that the collections have great research value, but that very few people are using them," notes Hunter. ${ }^{8}$ Arguing on behalf of increased openness, Byrd asserts the "key to eliminating, or at least decreasing, the marginalization of special collections has been active promotion of access to, and use of, those collections." "Turcotte emphasizes the importance of promotion to "nontraditional research populations" and theorizes that outreach increases awareness of collections and attracts scholars, enhances institutional prestige, adds to the body of scholarly knowledge, and encourages donations. ${ }^{10}$ The goals of outreach are increasing "the visibility, appeal, and accessibility of ... collections" and "to communicate the value of our collections." ${ }^{11}$ Publicly

3. Robert L. Byrd, "One Day It Will Be Otherwise," RBM: A Journal of Rare Books, Manuscripts, and Cultural Heritage 2, no. 2 (2001): 166; Carolyn Hansen, "Unhiding Maps @ brooklynhistory: Strategies for Outreach in Times of Austerity," Cartographic Perspectives 69 (2011): 48; Gregory S. Hunter, Developing and Maintaining Practical Archives: A How-To-Do-it Manual (New York: Neal-Schuman Publishers, 2003), 229; Josie B. Parker, "In the Public Interest," Journal of Library Administration 53, no. 4 (2013): 454.

4. Joe Clark, "Creative Fundraising through Campus Collaborations," Journal of Library Innovation 2, no. 2 (2011): 62-67; Michael Lorenzen, "Fund Raising for Academic Libraries: What Works, What Doesn't?" Library Philosophy and Practice (2010); Steven E. Smith, "From 'Treasure Room' to 'School Room': Special Collections and Education," RBM: A Journal of Rare Books, Manuscripts, and Cultural Heritage 7, no. 1 (2006): 31-39; Daniel Traister, "Public Services and Outreach in Rare Book, Manuscript, and Special Collections Libraries," Library Trends 52, no. 1 (2003): 87; Michelle Visser, "Inviting in the Rabble: Changing Approaches to Public Service and Access in Special Collections," Public Services Quarterly 1, no. 4 (2003): 29-41.

5. Micaela Morales and Jeff Rosen, "Accessing the Old and the New: Outreach via Web Exhibits and Archive Collections at the University of Arizona Library," Reference Librarian 32, no. 67/ 68 (2008): 58; Yolanda Theunissen, "Developing and Promoting Outreach Services for Middle Schools: Case Study of a Rare Map Library at a Public University," Journal of Map and Geography Libraries 3, no. 2 (2007): 6; Florence M. Turcotte, "One Community, One Story," in Librarians as Community Partners, ed. Carol Smallwood (Chicago: American Library Association, 2010), 91.

6. Allan Cho, "Bringing History to the Library: University-Community Engagement in the Academic Library," Computers in Libraries 31, no. 4 (2011): 17-18; Valerie A. Harris and Ann C. Weller, "Use of Special Collections as an Opportunity for Outreach in the Academic Library," Journal of Library Administration 52, no. 3 / 4 (2012): 296-303.

7. This article differentiates a single acquisition from a community-based documentation project or archive

8. Gregory S. Hunter, Developing and Maintaining Practical Archives: A How-To-Do-it Manual (New York: Neal-Schuman Publishers, 2003), 229.

9. Byrd, 163.

10. Florence M. Turcotte, "Outreach in Special Collections Librarianship," in Academic Library Outreach: Beyond the Campus Walls, ed. Nancy Courtney (Westport, Conn.: Libraries Unlimited, 2009), 91.

11. Ibid., 93. 
funded institutions have a concomitant responsibility to their constituents, but moreover, outreach and education simply make sense because they can lead to increased support for special collections. Resources can be widely shared, promoted to a diversified audience, and reach individuals who might otherwise be unaware of the existence of special collections and archives.

\section{Shifting Traditional Perceptions}

Special collections, or previously "a gentlemen's club of English or history professors" are becoming more transparent in their policies and programs, according to Visser. ${ }^{12}$ Examining four groups of stakeholders (undergraduates, scholars and researchers, $\mathrm{K}-12$ students, and community), she surmises that outreach programs have a positive effect on the visibility of special collections and their value as a community resource. Traister puts forth the premise that rare book and special collections libraries are "difficult and more forbidding to use"13 than other areas of a library and examines the role of promotion in altering those attitudes. With a focus on university research libraries, he postulates that advocacy is a significant consideration for special collections and suggests a shift from preservation to promotion. User-friendliness is paramount, and forms of outreach can encompass integrating materials into classroom instruction, digitization, and developing forums for connections with faculty and students.

\section{Reaching Out as a Function of Service}

Theunissen analyzes the idea of university service to the community and finds that negotiating a balance between access and preservation is imperative, along with aligning with the university's mission to serve the wider community. ${ }^{14} \mathrm{Har}-$ ris and Weller consider the internal institutional rewards that may accrue as the result of outreach efforts, ${ }^{15}$ starting with the premise that academic special collections departments have a "unique opportunity to serve as ambassadors for their institutions." ${ }^{16}$ If interactions are friendly and devoid of "attitude," activities can ultimately serve to demonstrate the value of special collections. ${ }^{17}$

\section{Developing Beneficial and Engaging Partnerships}

The ideal result of outreach is the creation of a relationship between the university library and its community (in other words, engagement). Turcotte surmises that "reaching out to the local community not only sets a good example for the students, it also improves town-gown relations." 18 To clarify the

12. Visser, "Inviting in the Rabble," 29-41.

13. Traister, "Public Services and Outreach," 87.

14. Theunissen, "Developing and Promoting Outreach Services for Middle Schools."

15. Harris and Weller, "Use of Special Collections," 294-303.

16. Ibid., 295.

17. Ibid., 296.

18. Turcotte, 100. 
distinction between outreach and engagement, Byrne delineates how engagement includes "both outreach and 'inreach' into the university" and "involves transfers in two directions; a partnership of exchange between the university and its constituents." ${ }^{19}$ Unlike a "transactional" model of engagement that places the university in the role of expert, the "social embeddedness" model views the "university as an equal partner with the public. Gupton identifies "social embeddedness" also as a "bidirectional and nonhierarchical" model of engagement in which the academic institution works collaboratively with the community as equals. ${ }^{20}$ The university and community build relationships with each other and share stakes in the outcome.

\section{Acquiring Spy Letters through Engagement Background}

In November 2005, an original letter written by General George Washington on September 24, 1779, from West Point, New York, describing activities of the Culper Spy Ring, failed to meet the minimum reserve price (estimated at $\$ 90,000$ $\$ 120,000)$ and sell at Christie's auction house in Manhattan. ${ }^{21}$ Although several local cultural organizations had publicly expressed interest in acquiring the letter, they simply did not have the funds to pursue it. ${ }^{22}$ Correspondence documenting the covert spy ring is rare and highly desired, but the cost of acquiring this letter was beyond these organizations' financial resources.

Assembled in 1778 by Major Benjamin Tallmadge at the request of Washington, the Culper Spy Ring operated on Long Island (concentrated in Setauket, New York) and in New York City and Connecticut during the American Revolutionary War. Credible reports about British activities were needed, and, as an intelligence officer, Tallmadge turned to his trusted childhood friends in Setauket. Spycraft, including codes, aliases, and the "sympathetic stain" (invisible ink) was used to conceal information and the identities of the ring's members. Abraham Woodhull (alias Samuel Culper Sr.) and Robert Townsend (alias Samuel Culper Jr.) gathered intelligence in British-occupied territories. Although Washington did not want to know the true identities of the spies, he was profoundly involved in giving directives and highly regarded reports from Townsend, as evidenced in his letters to Tallmadge. Townsend's double life remained a secret until the twentieth century, when Long Island historian Morton Pennypacker retained the services of graphologist Albert S. Osborn to confirm that the penmanship

19. John V. Byrne, "Outreach, Engagement, and the Changing Culture of the University," Journal of Higher Education Outreach and Engagement 20, no. 1 (2016): 53-58.

20. Jarrett T. Gupton, Amanda L. Sullivan, and Kate Johnston-Goodstar, "The Role of University Engagement in the Community," International Journal of Education Reform 23, no. 3 (2014): 181-90.

21. Bill Bleyer, "No Deal on Washington’s Spy Letter," Newsday (Nov. 16, 2005), A16.

22. Bill Bleyer, "Washington's Letter Goes on the Auction Block," Newsday (Nov. 14, 2005), A13. 
of Townsend and Culper Jr. was a match. Pennypacker's discovery was first announced at a meeting of the New York State Historical Society on September 27, $1930 .^{23}$

\section{Funding and Forming an Alliance}

In early 2006, library representatives (E. Christian Filstrup, former Dean of Libraries, and Kristen Nyitray, Head, Special Collections and University Archives, and University Archivist) learned the 1779 spy letter from "The (Malcolm) Forbes Collection of American Historical Documents: Part Three" had not sold in November 2005 and was scheduled to be auctioned again in spring 2006 with a lower minimum reserve price. SBU Libraries wanted to acquire the letter and make it a true public document (that is, not in private hands and inaccessible). There were distinct reasons why this specific letter was desired. No repository in the region had original, primary source documentation of the spy ring. Transcending academic and research boundaries, the letter provides concrete evidence of the spy ring's pivotal contributions to independence and the founding of the United States of America. It underscores the Three Village area's critical role during the American Revolution and the activities of Townsend, the secret agent from Oyster Bay, New York. Finally, in the letter, Washington gives explicit directives for how spies in Setauket should amass and conceal intelligence.

After discussing the significance and potential research impact of the historical letter, the library decided to pursue it in earnest. The district's New York State Assemblyman, Steven Englebright, a champion of preserving local history, was instrumental in fostering an alliance between SBU and heritage organizations. The first phase of the planning process was coordinating a series of meetings with university officials (former SBU President Shirley Strum Kenny) and library representatives (Filstrup and Nyitray) to discuss the feasibility of purchasing the letter. As a state-funded public institution, SBU has multiple revenue sources, including public, private, and research funds, and each type can be expended in a specific way. To navigate the complex fiscal process, library administration found it helpful to discuss the funding parameters with the Stony Brook Foundation, the nonprofit organization that raises and manages private funds to advance the university, and to consult with the university's budget office. To be competitive at the auction, a combination of state and privately raised funds was needed. Philanthropists and community members Dr. Henry Laufer (a former mathematics professor at SBU) and Marsha Laufer generously pledged funds to match the university's contribution, offset by New York State funds. With the intent to have the document reside

23. "American Spies Data Found in Old Chests: Washington's System of Espionage Revealed to Historian," The New York Times (Sept. 28, 1930), 29. 
permanently in Special Collections, the university tasked Filstrup and Nyitray with leading the efforts to acquire the letter. Nyitray was authorized to bid in person at the May 2006 auction. The process of registering with Christie's included creating an account for the university, providing government issued photo identification, and furnishing a financial reference.

With a procurement strategy in place, the next step was to cultivate inclusiveness with local stakeholders. The region shares a rich history. Embarking on a series of outreach efforts to foster collegiality and to galvanize the pursuit of the letter was important for community relations. While several heritage organizations had independently interpreted the story of the spy ring over the years, joint efforts had never been mounted. SBU was primed to lead this coordinated venture. Conversations were initiated with Raynham Hall Museum in Oyster Bay (the family home of spy Robert Townsend), the Three Village Historical Society in Setauket, the Ward Melville Heritage Organization in Stony Brook, and the Town of Brookhaven, in which Stony Brook and Setauket are unincorporated hamlets. The library stressed the importance of having the letter available at a research university where it would be curated, professionally conserved, and accessible to the community. Subsequently, a coalition of representatives from each organization was formed with the collective vision to bring the letter to Special Collections at SBU Libraries.

\section{Raising the Paddle: At the Auction}

The 1779 spy letter was scheduled for auction again at Christie's in New York on May 19, 2006, as part of "The Forbes Collection of American Historical Documents: Part Four," a sale featuring 253 items of Americana spanning the presidencies of George Washington to George H.W. Bush. After months of careful planning, an enthused "Culper" alliance met on the morning of the sale and traveled together to Manhattan. The entourage included representatives from SBU, local historical societies, the Town of Brookhaven, and Assemblyman Englebright. The letter was designated Lot 31 of 253 with an estimated appraised value of $\$ 100,000-\$ 150,000 .{ }^{24}$ Shortly after the auction commenced, some concern set in; bids on several lots were exceeding the values assigned to them. When Lot 31 was announced by the auctioneer, the excitement within the group grew. Several phone and in-person bids ensued; but, in the end, Nyitray held the winning paddle with an $\$ 80,000$ bid on behalf of SBU. Factoring in Christie’s 20 percent buyer's premium (an additional, administrative charge), the final cost was $\$ 96,000$.

24. Auction catalog, "The Forbes Collection of American Historical Documents: Part Four, Friday, 19 May 2006” (New York, N.Y.: Christie’s, 2006). 


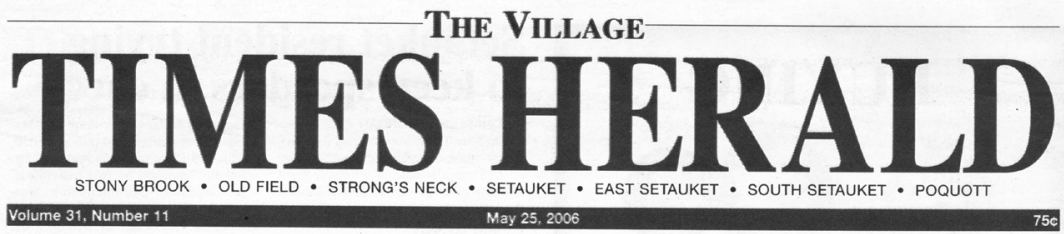

\section{George Washington spy letter acquired by SBU}

Coalition assembled by Englebright buys letter to Major Benjamin Tallmadge of the Setauket spy ring BY LEE LUTZ

Finally, 227 years after it was written, a letter "Our understanding was that in November a $\$ 90,000$ from General George Washington to Major Benjamin $\begin{aligned} & \text { bid was turned down," said Frank Turano, president of } \\ & \text { the Village Historical Society (TVHS). Turano }\end{aligned}$ Tallmadge, an integral part of the Setauket spy net- said that Englebright, learning of the letter, approached work during the Revolutionary War, is coming home Stony Brook University (SBU) President Shirley Strum o the The Dislage conthe University, the Three Village Historicat Society, beal comm "There a benefactor Henry Laufer of Setauket and Raynham "There are few remaining documents that tell the Hall Museum of Oyster Bay to purchase the historical story of espionage during the Revolutionary War" document. The creative and innovative display of coop- said Englebright. He explanned that by the very nature eration succeeded in acquiring the letter at an auction of what spies do, evidence of their work is rarely pre-

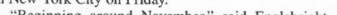
I became concerned it would be lost to Long belonging to the late billionairer, part of a collection advises Tallmadge regarding "Culper Junn," who in not sold at auction, even though it was offered along Oyster Bay. Townsend was a key player in the Setauket with many other items.
Continued on page $A 16$

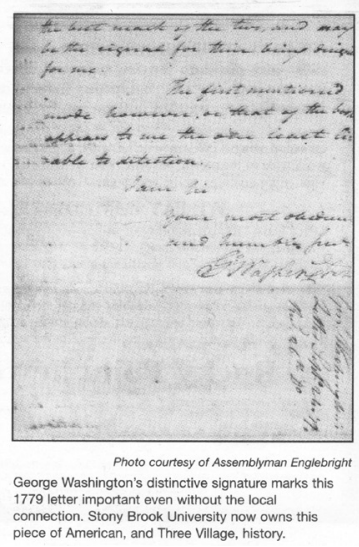

Illustration 1. "George Washington spy letter acquired by SBU: Coalition assembled by Englebright buys letter to Major Benjamin Tallmadge of the Setauket Spy Ring," The Village Times Herald, May 25, 2006.

Media outlets were quick to report on the acquisition, with emphasis on the collaborative nature of the acquisition project. Comments included:

- "...it was a team effort involving several players that made the quest successful." 25

- "Stony Brook now owns this piece of American, and Three Village, history...the main thing was to bring it back to a public university in Suffolk County." 26

Three years later, in February 2009, a second spy letter written by Washington in 1780 was acquired at the "Americana: Printed and Manuscript" auction. As with the first letter, it was purchased at Christie's with a mix of public and private funds and at a total cost of $\$ 60,000$.

\section{Impact and Outcomes}

\section{Focused Collection Development}

Collaborating with the local community led Special Collections to renew and articulate its collecting priorities. Prior to the acquisitions, local history was not a clearly defined area of focus for collection development, and resources were not specifically

25. Jennifer Choi, "Behind the Scenes, but Ahead of the Curve," The Village Times Herald (Dec. 27, 2007), A5.

26. Lee Lutz, "George Washington Spy Letter Acquired by SBU," The Village Times Herald (May 25, 2006), A1. 
QDear ten

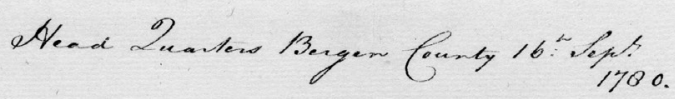

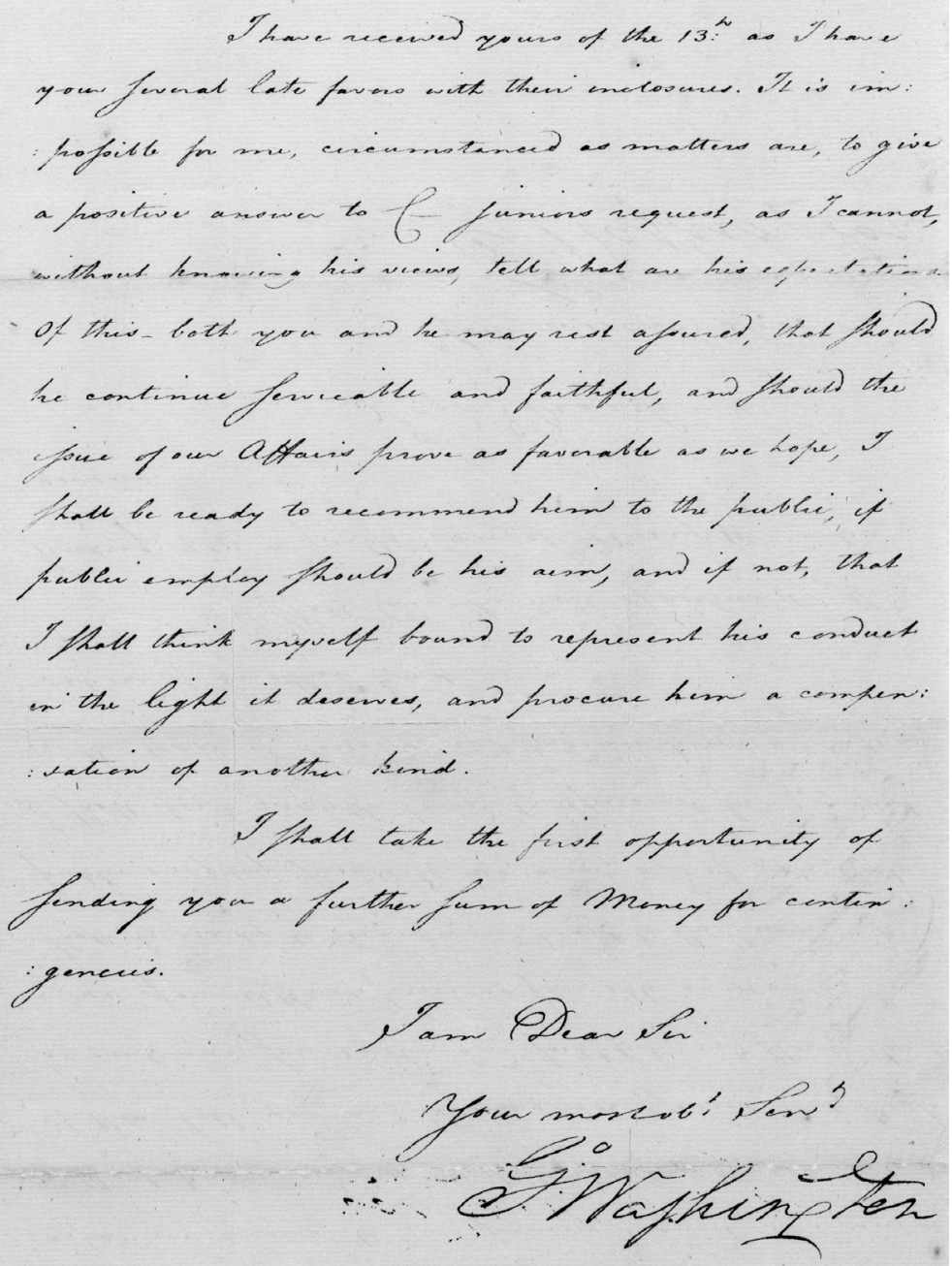

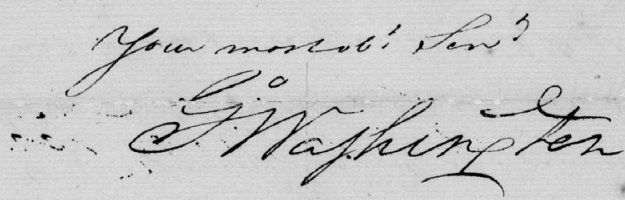

A.

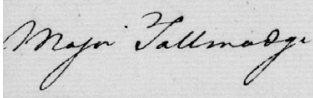

Illustration 2. Letter, George Washington to Benjamin Tallmadge, dated September 16, 1780. 
designated for acquisitions. Obtaining the spy letters was a significant achievement for the department and laid the foundation for the establishment of a Long Island Historical Documents Collection, with the mission to acquire, organize, preserve, and provide access to primary and secondary source material that documents the history of Long Island from the earliest settlers through the present, with a strong emphasis on the period of the American Revolution through the War of 1812. A dedicated account with privately raised funds was established in 2007 to acquire papers and books from dealers and at auctions. Several important documents were purchased as a result of this collecting initiative, including letters by James Jay (inventor of the invisible ink used by Washington), General Nathaniel Woodhull (Long Island patriot captured and mortally wounded by the British in 1776), and from Governor George Clinton of New York to Secretary of State Thomas Jefferson "ceding the Jurisdiction of certain Lands on Montauck Point" to the young United States for the establishment of one of the nation's earliest historic national monuments, the Montauk Point Light(house). ${ }^{27}$

\section{New Programs and Exhibitions}

Special Collections coordinated a celebratory event and unveiling of the 1779 letter on the SBU campus in October 2006. Attended by the public and university community, professional reenactors portraying Washington and Tallmadge greeted guests, read the letter, and fielded questions from the audience.

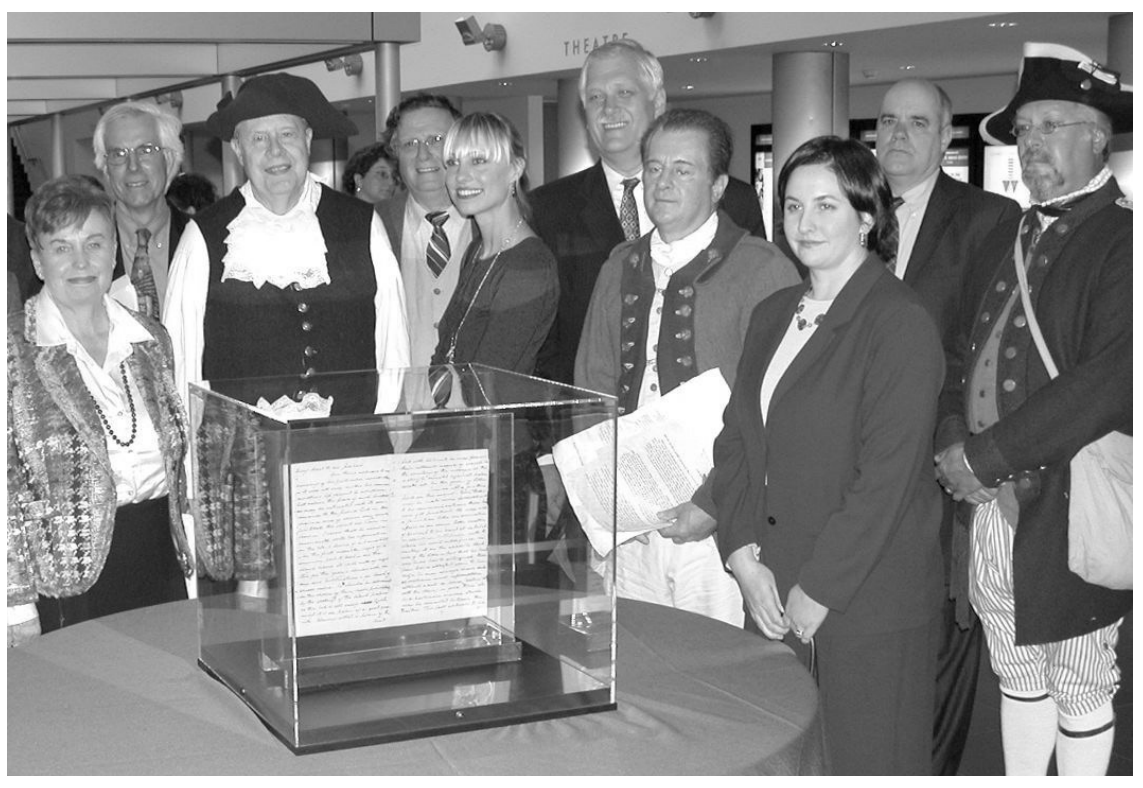

Illustration 3. Public unveiling of the 1779 Washington letter at Stony Brook University in 2006.

27. Letter, George Clinton to Thomas Jefferson, Feb. 21, 1793, Special Collections, Stony Brook University Libraries. 
This initial outreach program spurred the development of several new, mutually beneficial and collaborative activities in the Three Village area. A free scholarly conference titled "From Captivity to Freedom: Long Island during the American Revolution" was sponsored in 2007 by Special Collections and the Long Island Historical Journal. This event was attended by 150 historians, students, and community members. Featured speakers included Pulitzer Prize-winning author Edwin Burrows, Distinguished Professor, Brooklyn College, and Natalie Naylor, Professor Emerita, Hofstra University. Portions of the conference proceedings were published in the final print volume of the journal. ${ }^{28}$

By organizing exhibitions at off-campus venues, the department made strides in changing a traditional perception of inaccessibility to rare library materials and affirmed its commitment of service to the community. The letter made its first trip to Setauket in May 2008 on the occasion of the Brewster House (c.1665) in the Town of Brookhaven being placed on the New York State and National Registers of Historic Places. Caleb Brewster, a descendent, was a member of the Culper Spy Ring. The letter was subsequently displayed at Setauket Elementary School and at the Educational Center of the Ward Melville Heritage Organization in Stony Brook. Security was the main challenge with exhibiting the document at external venues. A police officer from Stony Brook University monitored the letter at locations not equipped with surveillance and other security measures.

In addition to hosting open houses, special viewings, scavenger hunts, and class visits, a comprehensive online research guide, "George Washington and the Culper Spy Ring," was developed by Nyitray and a graduate student intern under her mentorship. ${ }^{29}$ Statistics confirm it is consistently one of SBU Libraries' most accessed webpages. Digital surrogates of the letters are published on the guide and detailed finding aids with transcriptions place the letters in historic context. ${ }^{30}$

Community groups, in consultation with Special Collections, have incorporated the letters into their own outreach agendas. These synergies have fostered alliances with a diverse range of organizations and have been mutually beneficial. For example, the Long Island North Shore Heritage Area (LINSHA) developed a "Culper Spy Ring Audio Tour," which was "conceived...by board member Ira Costell of (neigh-

28. Conference papers, "From Captivity to Freedom: Long Island during the American Revolution," Long Island Historical Journal 20, no. $1 / 2$ (Fall 2007/Spring 2008): 112-73, available online at https:// dspace.sunyconnect.suny.edu/handle/1951/ 43865 [accessed 10 August 2016].

29. Kristen J. Nyitray and Lisa Patterson, "George Washington and the Culper Spy Ring," online subject guide, available online at http:/ / guides.library.stonybrook.edu/culper-spy-ring [accessed 15 August 2016].

30. Finding Aids for Special Collections and University Archives, Stony Brook University Libraries, available online at www.library.stonybrook.edu/special-collections-university-archives [accessed 15 August 2016]. 
boring) Port Jefferson after he saw a letter Washington wrote about the spy ring. ${ }^{31}$ The Three Village Historical Society, in conjunction with Special Collections, coordinated the 2011 conference "Rebels, Resistors, and Rioters: A Program of Lectures at SBU," which coincided with the society's interpretive exhibition "Spies: How a Group of Long Island Patriots Helped George Washington Win the Revolution.” The installation features a reproduction of SBU's 1779 letter, enlarged to span the length of a wall. Finally, in 2015, a community member conceptualized the event "Culper Spy Day: Our Revolutionary Story." More than a dozen local organizations have participated, with Special Collections hosting an open house featuring the two Washington letters. More than 1,200 adults and children attended in 2016.

\section{Increased Visibility: Media and Public Relations}

With each new acquisition, an announcement and press release with images is distributed and published on university websites to promote awareness, provide online access, and encourage visits to Special Collections. The auctions were reported in the Long Island-based daily newspaper Newsday and in local community news outlets. An article about the acquisition of the 1780 letter appeared in the May 2009 issue of Military History, complementing the featured cover story "George's Secret Spy Ring" and the article "Spymaster in Chief” by Edward G. Lengel, military historian and editor-in-chief of the Papers of George Washington. Media coverage and queries markedly increased in 2014 with the debut of the Culper-inspired AMC television program “TURN: Washington's Spies.” In 2014, Nyitray was interviewed for the cable series "Secrets of the Arsenal," nationally broadcasted on the America's Heroes Channel and in 2016 for the News 12 Long Island program "Long Island's Hidden Past." 32 She also discussed the preservation and conservation of the letters in a short film accompanying the 2015 exhibition "Long Island at War" at the Long Island Museum of American Art, History, and Carriages. ${ }^{33}$

\section{Recognition and Accolades}

Special Collections carved its niche for its commitment to curating primary source material about Long Island and has received extensive recognition as an archive of record for its contributions to documenting the spy ring. Public accolades for leading engagement and educational activities have been bestowed on the department and the university. The Three Village Historical Society presented the "Kate Wheeler Strong Award” in 2007 to Assemblyman Steven Englebright, Dr. and Mrs. Henry Laufer, and Stony Brook University "for their unique efforts surrounding the

\footnotetext{
31. Bill Bleyer, "The Spies of Long Island," Newsday (Apr. 13, 2011), A19.

32. "Long Island's Hidden Past," News 12 Long Island (2016), available online at http:/ /longisland. news12.com/features/long-island-s-hidden-past-1.5905498 [accessed 18 August 2016].

33. "George Washington Letters, 1779-1780," Long Island at War, exhibition (2014), The Long Island Museum of American Art, History, and Carriages, Stony Brook, New York.
} 
acquisition of the 1779 George Washington Culper Spy letter." ${ }^{34}$ In December 2009, Special Collections and University Archives received from the New York Board of Regents and New York State Archives the "Annual Archives Award for Program Excellence in a Historical Records Repository” for its outstanding archival program that contributes significantly to understanding the region's history." 35 The university was lauded for its "well managed archives" and "its efforts to provide access to the country's documentary heritage." ${ }^{36}$

\section{Conservation and Preservation Initiatives}

The acquisitions presented SBU Libraries with new opportunities to use external professional conservation services. Richard Feinberg (SBU Libraries Preservation Librarian, Emeritus) coordinated a series of conservation and preservation efforts in consultation with Nyitray. A fine arts mover transported the letters to the Conservation Center for Art and Historical Artifacts (CCAHA) in Philadelphia. Both letters were brittle at the edges and the iron gall ink writing medium was actively corroding the paper and forming holes. Surface cleaning, deacidification baths, hole mending, and humidification were performed. Housings needed to be fabricated for stability and for exhibition purposes. The letters were encapsulated between two sheets of polyester film, sealed, and then matted. The matted letters were then inserted into custom fabricated packages consisting of ultraviolet-filtering acrylic glazing and Marvelseal (a nylon, foil, polyethelene laminate) sealing the sides of the package. The packages were designed to protect them from particulate matter and help mitigate environmental changes. Many items located in Special Collections have consequently benefited as a result of the knowledge gained from this experience.

\section{Influence on Retelling Historical Narratives}

An unanticipated but noteworthy outgrowth was the influence of the acquisitions on elevating the study of the Culper Spy Ring. Past narratives were primarily written for a juvenile audience and relied heavily on folklore and anecdotes to explain how information was communicated among members of the ring. ${ }^{37}$ The account of Anna Strong hanging handkerchiefs among black petticoats on a clothesline to signal the cove in which Brewster awaited Woodhull has been passed down for many generations through oral tradition. It has also been taught in $\mathrm{K}-12$ curricu-

\footnotetext{
34. "Three Village Historical Society Presents Annual Awards," Three Village Historical Society press release, March 20, 2007.

35. "Stony Brook University Wins State Archives Award," New York State Archives press release (Oct. 6, 2009), available online at www.archives.nysed.gov/a/news/news_pressrelease_2009_10-06_E.shtml [accessed 20 August 2016].

36. "Stony Brook Special Collections and University Archives Wins State Archives Award," Stony Brook University press release (Dec. 9, 2009), available online at http://sb.cc.stonybrook.edu/news/gen eral/120809SpecialCollections.php [accessed 20 August 2016].

37. Beverly Tyler, "The Setauket Spy Ring Story," 11, available online at http:/ / spyring.emmaclark. org/SetauketSpyRingStory.pdf [accessed 1 October 2016].
} 
lum and perpetuated in literature, although primary source documentation or artifactual evidence does not exist. Concurrent to the first acquisition in 2006 was the publication of Alexander Rose's Washington's Spies: The Story of America's First Spy Ring. ${ }^{38} \mathrm{~A}$ well-researched and highly respected book, it does not address the use of a clothesline, but SBU's finding aids, websites, and programs, along with the Three Village Historical Society's "Spies" exhibition, all strongly emphasize the importance of consulting primary sources to formulate conclusions about the Culper Spy Ring. ${ }^{39}$ While a shift in discourse will take time, it has begun.

\section{Two Lessons from the Experience Develop Shared Goals}

A historical documents board was established by SBU Libraries in 2006 after the acquisition of the first letter. Membership included representatives from the university and local heritage organizations. Four types of activities emerged from conversations: Culper Spy Ring programs for $\mathrm{K}-12$ students, community events, a scholarly conference, and exhibitions. Each of these areas was developed and implemented in the first two years. However, shortly thereafter, the board dissolved. In hindsight, planning was focused on formulating and enacting immediate action items and did not fully consider the function of the board itself or developing long-term objectives for it. Developing shared goals and priorities, such as consortial collection development activities and fundraising, might have sustained the board and advanced it further. While the acquisitions continue to support community engagement, not all outreach efforts have been repeated due to the lack of potential growth and expansion. Fortunately, the dissolution of the board has not negatively impacted relationships, as new collaborative activities have emerged, including Special Collections' participation in Culper Spy Day 2016. Today, initiatives are developed by each individual institution, but when opportunities arise to form partnerships, they are considered and explored.

\section{Be Revolutionary}

SBU Libraries did not have a map or guide for how to manage a collaborative acquisition project. The objective of acquiring expensive manuscripts coupled with garnering support from external constituents was not part of the library's strategic plan or even on its radar. When the 1779 document became available, the organization had to immediately mobilize. Focused discussions were promptly held; subsequently, funds were identified and allocated. Previously, the library did not have the

38. Barbara Marhoefer and Fred Guardineer, Witches, Whales, Petticoats, \& Sails: Adventures and Misadventures from Three Centuries of Long Island History (Port Washington, N.Y.: I.J. Friedman Division of Kennikat Press, 1971); Katherine Kirkpatrick and Ronald Himler, Redcoats and Petticoats (New York: Holiday House, 1999); Lynn Groh, The Culper Spy Ring (Philadelphia: Westminster Press, 1969).

39. Alexander Rose, Washington's Spies: The Story of America's First Spy Ring (New York: Bantam, 2006). 
financial resources to pursue valuable documents. Rapport had to quickly develop with local historical organizations. To expedite the process, library representatives identified relevant institutions and traveled off-campus to nurture communications. In the planning process, an organization should consider building in time to cultivate relationships that may fortuitously lead to new funding sources. Unique and diversified programming also needed to be devised to support and promote the project. Compelling lectures, interpretative exhibits, and historic reenactments were produced in a series of public events. Although this flurry of activity did not lead to increased staffing, it did kindle creative, out-of-the-box thinking. All of these efforts had moments of uncertainty, but they evolved into dynamic activities that began an uncharted, yet exciting path for library outreach efforts. The results were a new mode for collection acquisition and expanded methods of engaging with the university and external communities.

\section{Conclusion}

Engagement can begin at the outset of an acquisition project. While "town and gown" issues, budgetary constraints, and lack of institutional support may be obstacles, they can also be catalysts for action. Synergistic collaborations with nonprofits, private organizations, and donors can unify disparate groups while fulfilling educational and research aspirations. Open and collegial dialogues can also lead to the emergence of new and dynamic partnerships and subsequently be impactful, as "greater public awareness of archives results in greater potential public support for their work." 40

With the acquisition of the two Washington letters, SBU Special Collections formed mutually beneficial relationships with local cultural heritage institutions. The initiative established a collaborative acquisition model that can be emulated and repeated in the future. The process informed and refocused collection development priorities with the founding of a Long Island Historical Documents Collection and a dedicated fund to purchase acquisitions. The letters elevated the profile and reputation of the repository on statewide and national levels through increased media coverage and the bestowal of educational awards. It took a village-in this case, the Three Villages-but "Spies in the Archive" may serve as an example of how community outreach and engagement activities can affect a "revolution" at other institutions.

40. Kate Theimer, "Introduction," in Outreach: Innovative Practices for Archives and Special Collections, ed. Kate Theimer (Lanham, Md.: Rowman \& Littlefield, 2014), vii. 


\section{Congratulations to the winners of the ACRL/RBMS Katharine Kyes Leab and Daniel J. Leab American Book Prices Current Exhibition Catalogue Awards}

\section{CATEGORY 1 WINNER (Expensive)}

The University of Toronto's Thomas Fisher Rare Book Library for So Long Lives This: A Celebration of Shakespeare's Life and Works 1616-2016

\section{CATEGORY 2 WINNER (Moderately Expensive)}

The Mills College Center for the Book \& Flying Fish Press for Reading the Object: Three Decades of Books by Julie Chen

\section{CATEGORY 2 HONORABLE MENTION (Moderately Expensive)} The University of Pennsylvania Libraries Kislak Center for Special Collections, Rare Books and Manuscripts for Covered With Vines: The Many Talents of Ludwig Bemelmans

\section{CATEGORY 3 WINNER (Inexpensive)}

Georgetown University's Booth Family Center for Special Collections for Undiscovered Printmakers: Hidden Treasures at Georgetown University Library

\section{CATEGORY 4 WINNER (Brochures)}

Johns Hopkins University Special Collections for Lost \& Found in the Funhouse: The John Barth Collection

\section{CATEGORY 5 WINNER (Electronic)}

The University of Maryland Libraries' Special Collections and University Archives for Alice 150 Years and Counting... The Legacy of Lewis Carroll: Selections from the Collection of August and Clare Imholtz

The winning catalogues will be on display during the Booksellers' Showcase at the 2017 RBMS Conference in Iowa City, June 20-23, 2017.

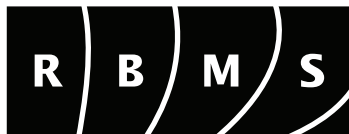

